\title{
Reconstructing past forest status using inventory and tree ring data to support uneven-aged forest management
}

\author{
Ladislav Kulla ${ }^{1 *}$, Michal Bošel'a², Vlastimil Murgašํㅜ , Joerg Roessiger ${ }^{1}$, Vladimír Šebeň ${ }^{1}$ \\ ${ }^{1}$ National Forest Centre - Forest Research Institute Zvolen, T. G. Masaryka 2175/22, SK - 96092 Zvolen, Slovak Republic \\ ${ }^{2}$ Technical University in Zvolen, Faculty of Forestry, T. G. Masaryka 24, SK-960 53 Zvolen, Slovak Republic
}

\begin{abstract}
The decision to change forest management system from the traditional even-aged to the selection one based on statistical inventory is often limited by a missing previous inventory. To avoid this issue, we used available forest inventory data from ca 2000 ha of mixed uneven-aged beech-fir-spruce-pine forest and tree ring data from 831 trees to reconstruct forest status from one decade ago. For this purpose, we have created three sets of species-specific models: 1) diameter-stump models to reconstruct the diameter of missing trees, 2) diameter-increment models based on tree ring data to estimate past diameters, and 3) height-diameter models to estimate past tree heights. This approach has allowed us to completely reconstruct the state of the forest as it was ten years ago and use the results as a substitution for a previously missing inventory.
\end{abstract}

Key words: stump-diameter models; height-diameter models; diameter increment models; forest inventory; selection forest management

Editor: Róbert Marušák

\section{Introduction}

Selection management systems are used only rarely in Central and Eastern Europe. Contrary to that, the importance of uneven-aged and/or close-to-nature forest management as defined by Möller (1922) and as newly summarized e.g. by Bauhus et al. (2014) is expected to increase in the future. Uneven-aged forests are considered to better fulfil the requirements for multipurpose forest use and the provision of ecosystem services than even-aged forests (Pukkala 2016). The main reason for their limited use, in extreme cases even for disallowing of selective logging, is a lack of adequate inventory and planning tools (Dvorak 2000), more easier to apply and cheaper than traditional methods developed already in $19^{\text {th }}$ century.

Control methods (Biolley 1887) used for planning in uneven-aged forests and selective logging management are based on periodical forest inventories using the same method. Other relatively simple methods for modelling and management planning, particularly in uneven-aged forests, are matrix transition models. These models are derived from population growth models (Leslie 1945; Buongiorno \& Michie 1980; Pukkala et al. 2009; Roessiger et al. 2016) which are also based on a regular inventory cycle. At present, a lot of attention is given to single tree-based growth simulators (as summarized e.g. by Hasenauer 2006) able predict forest development after one inventory. Nevertheless, their application is not very widespread due to the complexity of their inputs and knowledge of their application in selection forests is largely uknown.

There are two main non-destructive sources of data on tree growth. The first one is based on a regular inventory cycle whilst the second uses tree ring chronologies (Biondi 1999). Tree rings provide valuable information on individual tree growth, stand history and dynamics, and even past climate (e.g. Fritts 1976; Schweingruber et al. 1978). If a decision is made to change a management system in forests from even-aged based on stand mensuration to uneven-aged using an initial statistical inventory, previous inventory data crucial for the calibration of control method based planning models are missing. In such a case, the combination of forest inventory data with tree ring data is needed, often deemed essential (Biondi 1999; Lindbladh et al. 2007).

The aim of the study is to design procedure based on the existing inventory and tree ring data for statistical reconstruction of past forest status in the absence of previous forest inventory. 


\section{Material and Methods}

\subsection{Study area}

The study area represents the "Pro Silva" model forest unit Smolnícka Osada covering 2,132 hectares of forest in the Volovské Mountains in the Central West Carpathians $\left(48^{\circ} 44^{\circ} \mathrm{N}, 20^{\circ} 46^{\circ} \mathrm{E}\right)$. The selection management system has been applied in the mixed beech-fir-spruce forests with admixed pine for more than 50 years during which uneven-aged forest structures have formed (Fig. 1). The geological bedrock is build mainly by phyllites with a dominant representation of dystric and typical cambisols. The altitude ranges from 440 to $1,150 \mathrm{~m}$ above sea level, within which the 4th (beech) and 5th (fir-beech) altitudinal vegetation zones are most prevalent with minor presence of 6th (beech-fir-spruce) zone. Despite the dominance of complex uneven-aged stand structures, traditional forest mensuration based on yield tables is still used for forest planning in a ten year cycle.

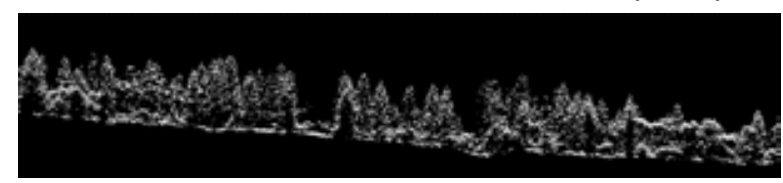

Fig. 1. A typical profile of Smolnícka Osada model forest derived from airborne laser scanning data.

\subsection{Extended forest inventory}

To support transition to management methods more suitable for uneven-aged forests, the first statistical inventory was completed in 2014. Inventory data were collected from 344 inventory plots (IP) established in a $250 \times$ $250 \mathrm{~m}$ grid, each of which comprised a minimum of 20 trees with variable plot radii between 7.5 and $20 \mathrm{~m}$. Data on diameter at breast height $(d b h)$, tree height, crown length, crown quality (A - big/dense, B - medium, C small/sparse), stem quality (A - high, B - medium, C low) and stem damage ( 0 - undamaged, 1 - damaged) were collected for each tree with $d b h>8 \mathrm{~cm}$. The position of each tree was ascertained by polar coordinates. Additionally, position and diameter measurements from all stumps of trees harvested in the last decade were taken. For this purpose, a catalogue of visual parameters, mechanical properties and signs of biotic colonisation of stumps from all targeted species and different postfelling periods was compiled using forest management records from the model area. According to species specific scales, three age categories of stump age were estimated (A-1 to 3, mean 2 years; $\mathrm{B}-4$ to 7 , mean 5 years; $\mathrm{C}-8$ to 10 , mean 9 years after cutting). Finally, on the subset of 87 IP in the $500 \times 500 \mathrm{~m}$ grid, tree cores were taken for tree ring analysis in a pattern which reflected variations in tree sizes, altitude and stand conditions representing independent variables of the models described in next text. The data was processed by standard MS Office tools and models were derived using R-package ( $R$ core team, 2016) and STATISTICA.12 (StatSoft, 2013).

\subsection{Diameter-stump models}

Diameter-stump models based on the data obtained from tree stumps are necessary for the reconstruction of missing trees cut during the last decade. For this purpose, National Forest Inventory data (NFI 2015) from 496 NFI plots located only on productive sites in the $4^{\text {th }}-6^{\text {th }}$ altitudinal vegetation zones were used to calculate simple one factor linear models. Data was sourced from 1,375 beeches, 1,537 spruces, 327 firs and 88 pines with simultaneously measured diameter at breast $(1.30 \mathrm{~m})$ and stump ( $0.25 \mathrm{~m}$ as mean) height.

\subsection{Diameter increment models}

An extensive dendrochronological material including cores from 334 beech, 280 fir, 144 spruce and 63 pine trees from 75 model area inventory plots in a $500 \times 500$ grid was used for diameter increment modelling. One core was taken from each pre-selected tree at breast height in a direction perpendicular to the slope. Due to high unexplained variability of absolute increments obtained from cores (tree ring widths), diameter increment models were constructed for relative diameter increment $(r d i)$. Dependent variable $r d i$ was calculated as a ratio of double mean tree ring width from the past ten year period to tree $d b h$. Since $r d i$ has shown an exponentially decreasing relationship with $d b h$, power and exponential functions have been chosen for modelling. The following factors have been tested as independent variables: diameter at breast height $(d b h)$, relative crown proportion to the tree height $(c p)$, crown quality assessed through crown vitality and density to three categories A, B and C $(c q)$, mean stand diameter $(d g)$, stand timber volume per hectare ( $v h a)$, species specific site index $(s i)$ and basal area proportion competition index $(\mathrm{Clg})$. $\mathrm{Clg}$ have been assessed as highly relevant in relation to diameter increment by Bošel'a et al. (2015), calculated according to Formula 1:

$$
C I g=\sum_{j=0}^{n} \frac{g_{j}}{g_{i}}
$$

Where: $C I g$ is basal area proportion index, $g_{i}$ is basal area of $i$ th target tree, $g_{j}$ is basal area of a $j$ th neighbour. All trees on IP were considered as neighbours. Variable IP radius resulting to approximately the same number of trees on plots was assumed to ensure comparable results.

\subsection{Height-diameter models}

Data from a $500 \times 500$ grid was used for the computation of local height curves. Only trees with no crown and/or stem abnormalities such as broken top, tilted stem etc. were included in the analysis. Except for $d b h$ as a main predictor, the following factors were tested for their influence on the model: mean stand diameter $(d g)$, stand tim- 
ber volume per hectare $(v h a)$, species specific site index (si) and basal area proportion competition index ( $\mathrm{CIg})$. For all species, universal three-parameter exponential function with inflexion point well-fulfilling biological assumptions has been computed.

\subsection{Reconstruction of past forest status}

Finally, forest status from ten years ago has been statistically derived in three steps. Firstly, $d b h$ of each individual tree felled during the past decade was reconstructed using a diameter-stump model (Formula 2 in the Results section). Secondly, $d b h$ of all trees was re-calculated for the tenth year before the present inventory (2004) using diameter increment models (Formula 3-6 in the Results section). Thirdly, the height of trees in the same time point was calculated using height-diameter models (Formula 7 in the Results section). In the case of felled trees with $d b h$ reconstructed by diameter-stump models, the felling year estimated within stump inventory was regarded to consider increment before tree was cut. Missing model parameters of felled trees $(c p, c q)$ were replaced by mean values, while stand parameters $(d g$, $v h a, s i$ ) generally were taken from inventory 2014 . This way, we were able to statistically reconstruct the missing previous inventory 2004. Its data was compared with an existing completed inventory 2014, and information about forest dynamics during last decade can be derived.

\section{Results}

\subsection{Diameter-stump models}

One factor linear diameter-stump model appeared to be sufficient for tree diameter $(d b h)$ estimation from stump diameter (Formula 2).

$$
d b h=a+b \times d s
$$

Where: $d b h$ is diameter at breast height $(\mathrm{mm}), d s$ is stump diameter (mm), and $a, b$ are species specific coefficients (Table 1).
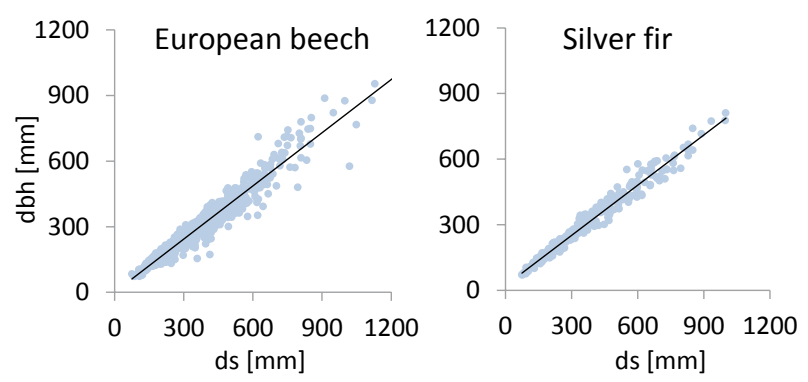

Table 1. Coefficients and statistics of diameter-stump models based on NFI data (Formula 2).

\begin{tabular}{lccccc}
\hline \multicolumn{1}{c}{ Species } & $\mathrm{a}$ & $\mathrm{b}$ & $\mathrm{n}$ & $\mathrm{R}^{2}$ & $\mathrm{RMSE}$ \\
\hline European beech & $0.152^{\mathrm{n}}$ & $0.810^{1}$ & 1375 & 0.95 & 28.0 \\
Silver fir & $22.228^{1}$ & $0.765^{1}$ & 327 & 0.97 & 24.2 \\
Norway spruce & $26.811^{1}$ & $0.706^{1}$ & 1537 & 0.96 & 27.2 \\
Scots pine & $-2.010^{\mathrm{n}}$ & $0.843^{1}$ & 88 & 0.97 & 19.5 \\
\hline $\mathrm{R}^{2}$ - coefficient of determination, RMSE - root mean square error, significance codes: ${ }^{1<0.001}$, \\
${ }^{2} 0.001-0.01,{ }^{3} 0.01-0.05,{ }^{n}>0.05$.
\end{tabular}

Figure 2 shows clear linear relationship between $d b h$ and $d s$. If the different tree species have the same stump diameter value $d s$, then the smallest $d b h$ is expected for Norway spruce and largest dbh for Scots pine. The reasons are probably related to species specific differences in root swelling formation.

\subsection{Diameter-increment models}

A multiple power model with a different set of statistically significant variables was selected for a relative diameter increment estimation of beech, fir and spruce (Formula $3-5)$. An exception was pine, where exponential function appeared to be more suitable (Formula 6).

European beech: $r d i=a \times d b h^{b} \times c p^{c} \times c q^{d} \times v h a^{e}$

Silver fir: $\quad r d i=a \times d b h^{b} \times c p^{c} \times c q^{d} \times d g^{e}$

Norway spruce: $\quad r d i=a \times d b h^{b} \times c p^{c} \times v h a^{d}$

Scots pine:

$r d i=a \times e^{(-b \times d g+c \times s i)}$

Where: $r d i$ is relative diameter increment (\%), $d b h$ is diameter at breast height $(\mathrm{mm}), c p$ is relative crown proportion (\%), $c q$ is crown quality, $d g$ is mean stand diameter $(\mathrm{mm})$, vha is stand timber volume per hectar $\left(\mathrm{m}^{3}\right), s i$ is species specific site index $(\mathrm{m})$, and $a, b, c, d, e$ are species specific coefficients (Table 2 ).

Table 2. Coefficients and statistics of local diameter increment models (Formula 3-6).

\begin{tabular}{|c|c|c|c|c|c|c|c|c|}
\hline \multirow{2}{*}{ Species } & \multicolumn{5}{|c|}{ Parameter estimates } & \multirow[b]{2}{*}{$\mathrm{n}$} & \multirow[b]{2}{*}{$\mathrm{R}^{2}$} & \multirow[b]{2}{*}{ RMSE } \\
\hline & $\mathrm{a}$ & $\mathrm{b}$ & c & $\mathrm{d}$ & $\mathrm{e}$ & & & \\
\hline Beech & $6.12^{2}$ & $-0.827^{1}$ & $0.619^{1}$ & $-0.420^{1}$ & $-0.275^{1}$ & 319 & 0.57 & 0.006 \\
\hline Fir & $13.73^{2}$ & $-0.676^{1}$ & $1.322^{1}$ & $-0.547^{1}$ & $-0.487^{1}$ & 283 & 0.69 & 0.004 \\
\hline Spruce & $732.8^{\mathrm{n}}$ & $-1.299^{1}$ & $1.838^{1}$ & $-0.733^{1}$ & - & 111 & 0.74 & 0.005 \\
\hline Pine & $0.004^{\mathrm{n}}$ & $0.006^{1}$ & $0.052^{3}$ & - & - & 64 & 0.34 & 0.002 \\
\hline
\end{tabular}
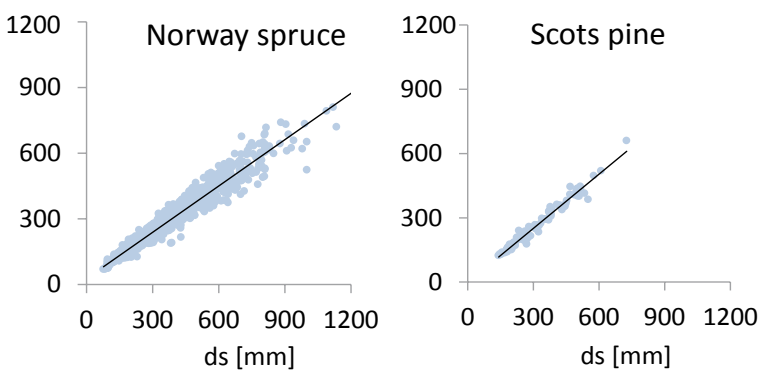

Fig. 2. NFI data shows high species specific correlation between $d b h$ and $d s$. 
From the tested factors, only basal area proportion index $(\mathrm{Clg})$ failed to be a significant $r d i$ predictor for any of the species. Its influence was overshadowed by single tree crown parameters $c p, c q$, simultaneously with one of the stand density or maturity indicators vha and/or $d g$. Fir showed locally the highest diameter increment in the last decade, followed by beech (Fig. 3). For both species $r d i$ dynamics are well described by 4 -parameter power function with a similar set of predictors. Spruce $r d i$ was comparable in the lowest $d b h$, but with increasing $d b h$ began to fall dramatically. In contrast to the previous models, $c q$ parameter was missing in the spruce $r d i$ model. Partial relation of current $c q$ status to the spruce $r d i$ together with strong $r d i$ decrease with increasing $d b h$ can be explained by acute spruce decline of older trees caused by biotic agents common in the model area over the last two decades. Pine was generally the lowest with the weakest relationship to the tested predictors. Pine $r d i$ model with only two stand related predictors differing from other species explained a lower proportion of rdi variability.

\subsection{Height-diameter models}

Height curves of all species are naturally dependent on $d b h$. In addition, they appeared to be significantly influenced by mean stand diameter $(d g)$, what is biologically well proven. Height-diameter curves are shifting upwards during stand development and the stand development
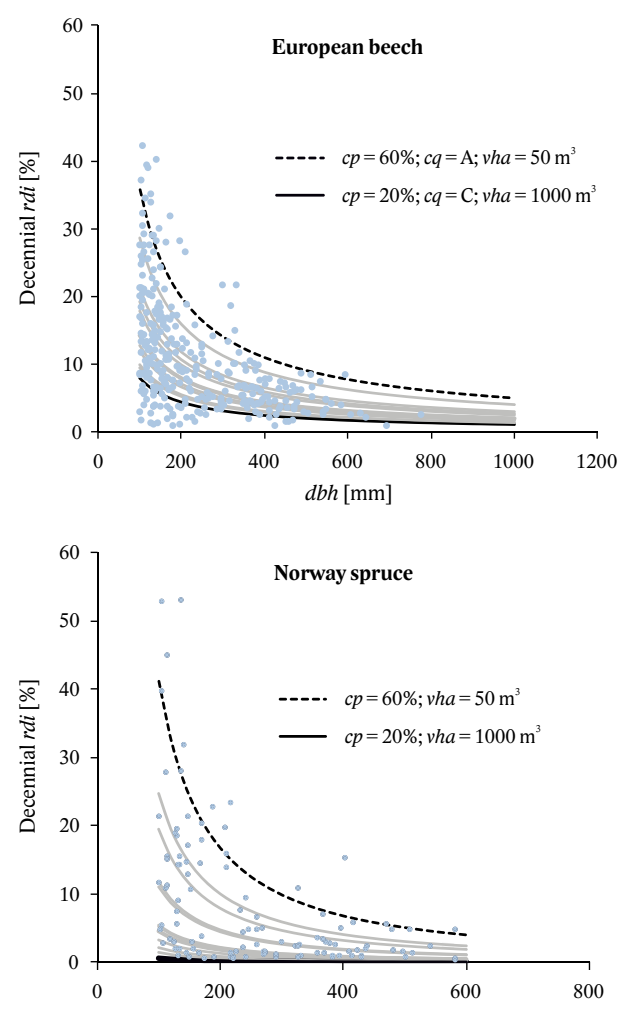

(known as growth stages) is well approximated by the mean stand diameter. A general model for all species was defined by Formula 7 .

$$
h=1.3+a \times e^{(-b / d b h+c / d g)}
$$

Where: $h$ is tree height (m), $d b h$ is diameter at breast height $(\mathrm{mm}), d g$ is mean stand diameter $(\mathrm{mm})$, and $a$, $b, c$ are species specific coefficients (Table 3 ).

Table 3. Coefficients and statistics of local height-diameter models (Formula 7).

\begin{tabular}{lcccccc}
\hline \multirow{2}{*}{ Species } & \multicolumn{5}{c}{ Parameter estimates } \\
\cline { 2 - 6 } & $\mathrm{a}$ & $\mathrm{b}$ & $\mathrm{c}$ & $\mathrm{n}$ & $\mathrm{R}^{2}$ & RMSE \\
\hline European beech & $46.998^{1}$ & $170.308^{1}$ & $-33.090^{3}$ & 214 & 0.79 & 3.94 \\
Silver fir & $61.268^{1}$ & $238.712^{1}$ & $-56.790^{1}$ & 175 & 0.87 & 3.64 \\
Norway spruce & $55.016^{1}$ & $194.602^{1}$ & $-49.755^{1}$ & 74 & 0.85 & 2.91 \\
Scots pine & $51.098^{1}$ & $117.219^{1}$ & $-83.941^{1}$ & 64 & 0.59 & 2.77 \\
\hline
\end{tabular}

$\mathrm{R}^{2}$ - coefficient of determination, RMSE - root mean square error, significance codes: ${ }^{1<0.001}$, ${ }^{2} 0.001-0.01,{ }^{3} 0.01-0.05,{ }^{\mathrm{n}}>0.05 .7$.

Fir showed the highest height-growth potential, followed by spruce, pine and beech (Fig. 4). As expected, the shape of height curves differs between tree species. While at the middle stand diameter $(d g=36 \mathrm{~cm})$ and $d b h$ $=20 \mathrm{~cm}$ pine was the tallest $(23 \mathrm{~m})$, followed by spruce $(20 \mathrm{~m})$, beech $(19.5 \mathrm{~m})$ and fir $(17 \mathrm{~m})$, at $d b h=50 \mathrm{~cm}$ fir was the tallest ( $34 \mathrm{~m}$ ), followed by spruce and pine (33.5), and finally beech ( $32 \mathrm{~m})$. Also at higher $d b h$ the fir curve remained steep, whilst for other species, pine in particular, the curves became flatter. The pine heightdiameter model was the most (beech the least) affected by stand growth stage expressed by $d g$.
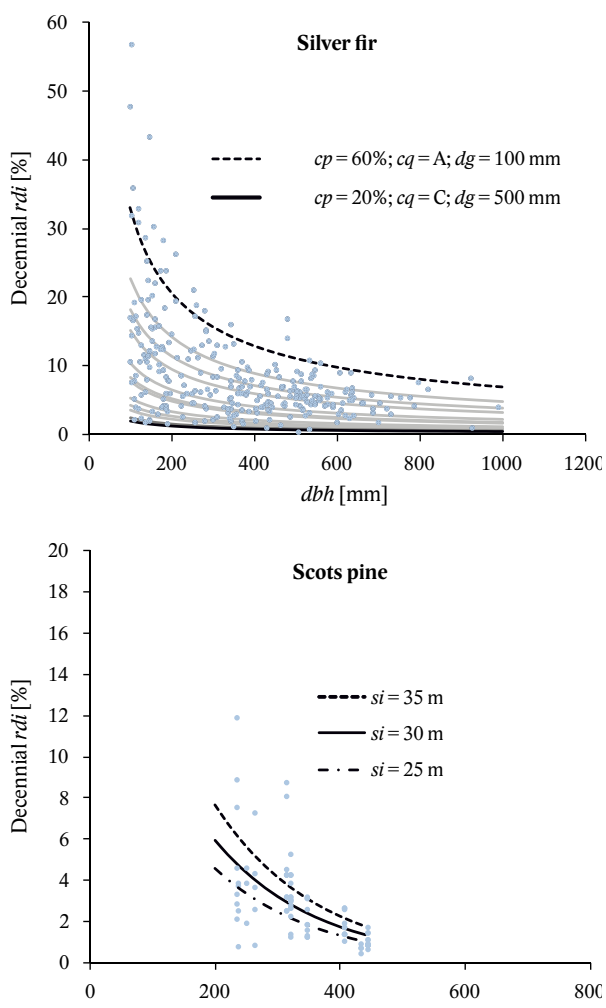

Fig. 3. Species specific diameter increment model characteristics at different levels of significant variables against the original data background. 

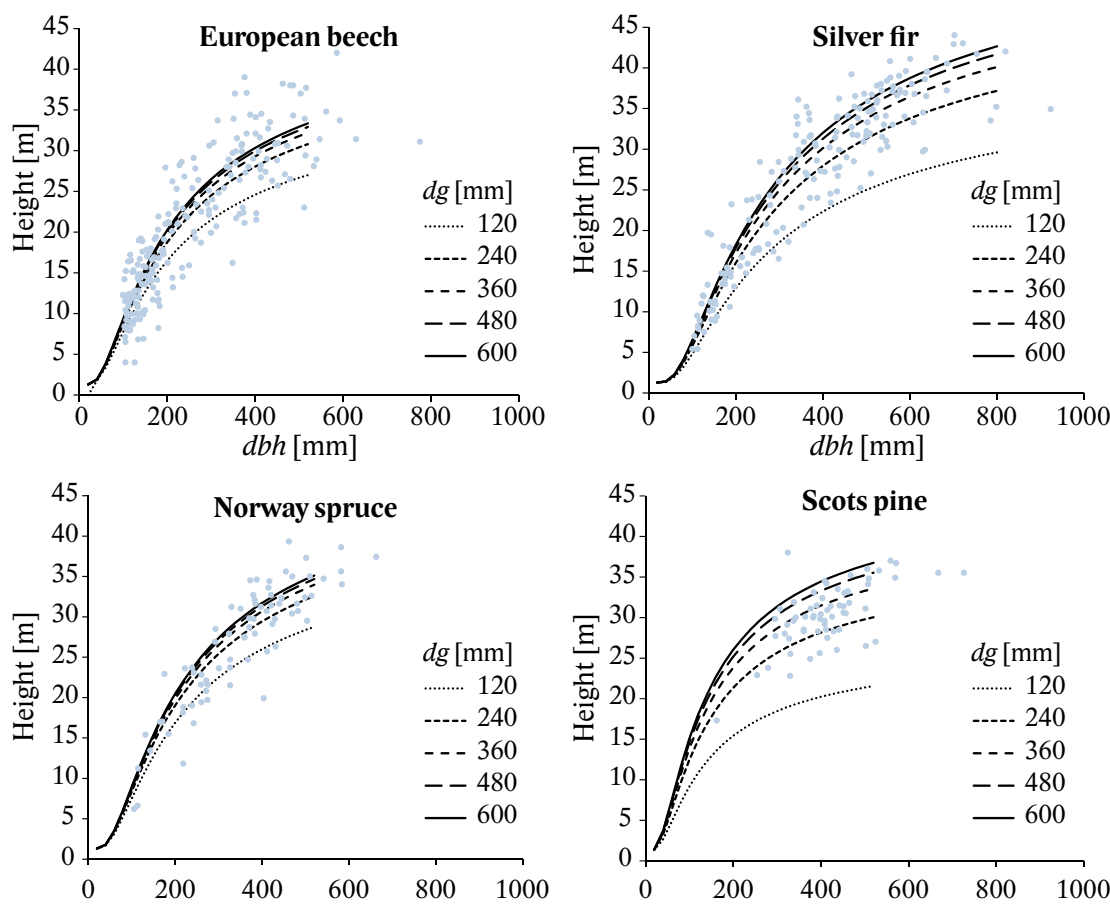

Fig. 4. Species specific height-diameter model characteristics at different mean stand diameter $(d g)$ against the original data background.
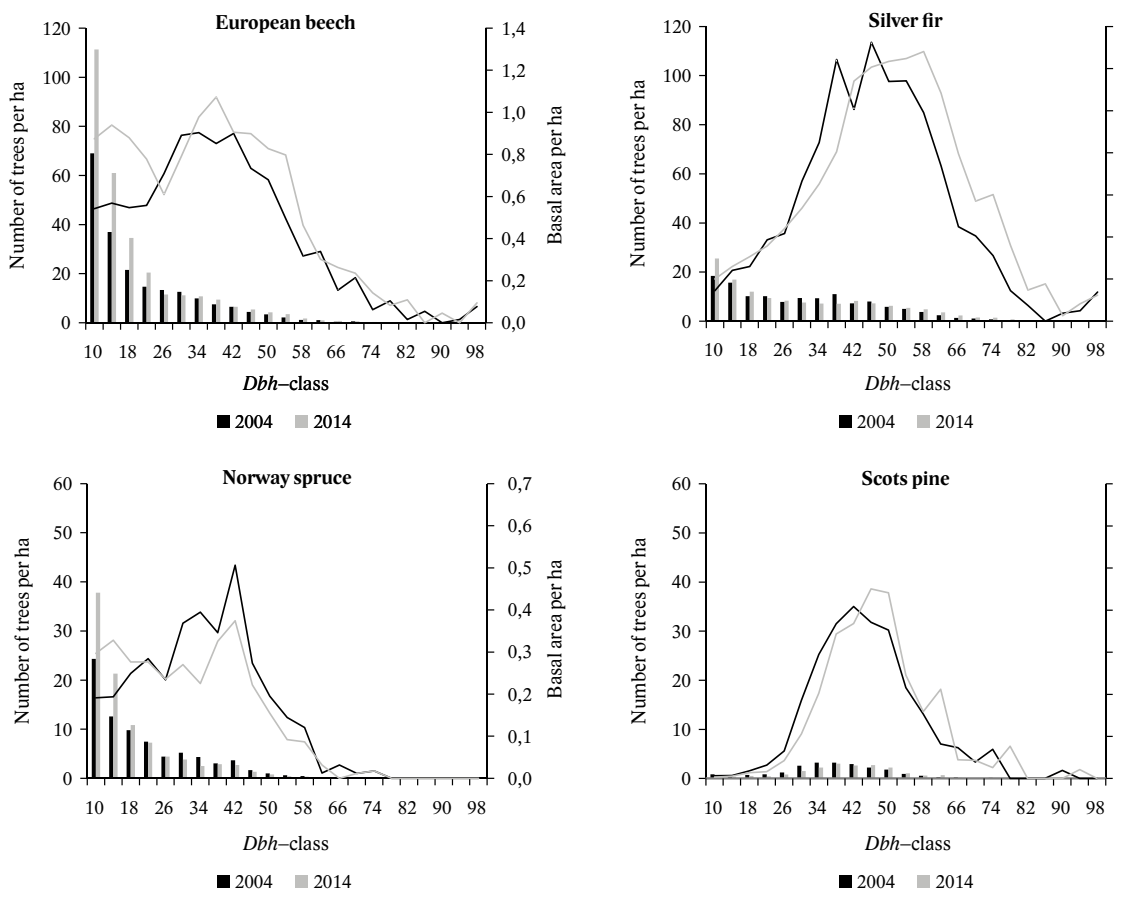

Fig. 5. Changes in species specific $d b h$ (columns) and basal area (lines) distribution by $4-\mathrm{cm} d b h$ classes between statistically reconstructed inventory in 2004 and real inventory in 2014.

\subsection{Statistically reconstructed past forest status}

Figure 5 illustrates forest status in 2004 estimated statistically using the set of models described above against the results of inventory in 2014. Shade tolerant species such as fir, beech and spruce showed expo- nentially decreasing $d b h$ distribution and accelerated ingrowth in the last decade in contrast to pine, which is not able to regenerate in shade and therefore also survive prospectively in such a forest structure. Distribution of the basal area $(b a)$ of all species except spruce shifted more or less to the higher $d b h$ classes, what caused an 
increase of total standing timber volume, while $b a$ of the beech is higher almost for all $d b h$ classes suggesting that mainly beech gradually replace the declining spruce. A general decrease of spruce $b a$ due to mortality caused by bark beetles was compensated by the increment of other species. There might be more causes behind vigorous regeneration and ingrowth processes of shade tolerant species in the understorey observed in the last decade. Fairly intensive felling in the 1994-2004 period (72 $\mathrm{m}^{3} /$ ha according to FMP) was probably the main cause combined with larger canopy openings following felling of declining spruce trees, and a general shift of residual stock to higher $d b h$ classes enabling understorey regeneration as described e.g. by Olivier \& Larson (1996).

Table 4 summarizes fundamental parameters of the model forest: growing stock, felling and increment, as well as its dynamics during the period of interest. Increment was calculated simply as a difference of growing stock volume between 2014 and 2004 regarding total felling in the period (Formula 8 ). All trees with measured (2014) or reconstructed (2004) dbh higher than $8.0 \mathrm{~cm}$ were involved in stock, hence increment includes also ingrowth of new trees.

$$
\text { Increment }=\text { Stock }_{2014}-\text { Stock }_{2004}+\text { Felling }
$$

Table 4. Development of Smolnicka Osada model forest based on the real and statistic inventory reconstructed by the models.

\begin{tabular}{|c|c|c|c|c|}
\hline & \multirow{2}{*}{ Year } & Stock & Harvest & Increment \\
\hline & & \multicolumn{3}{|c|}{$\mathrm{m}^{3} / \mathrm{ha}( \pm \mathrm{se}$ 95\%) } \\
\hline $\begin{array}{l}\text { Reconstructed inventory } \\
\text { Real inventory }\end{array}$ & $\begin{array}{l}2004 \\
2014\end{array}$ & $\begin{array}{l}343 \pm 21 \\
386 \pm 23\end{array}$ & $57 \pm 8$ & $100 \pm 19$ \\
\hline
\end{tabular}

\section{Discussion}

\subsection{Diameter-stump models}

Several authors have reported that using simple linear regression is fully justified for modelling the $d b h$-stump diameter relationship (e.g. Myers 1963; Hann 1976; Bylin 1982; Corral-Rivas et al. 2007; Özçelík et al. 2010). However, models incorporating stump height as a predictor variable can be superior. This is mostly correct for trees cut at different stump heights. In cases where stump height is not included in the model and there is a high variability of stump heights, the predictive ability of the model is low (Chhetri \& Fowler 1996; Pond et al. 2014). In our study, we have calculated a simple linear regression model to predict diameter at breast height from the stump diameter outside bark. The stump height was not considered as a predictor variable given the assumption that all trees were cut at the height where stem started to be regular, i.e. not much deformed by root swells. Our species-specific models indicated the total $d b h$ variance of $95 \%$ for beech, $96 \%$ for spruce, and $97 \%$ for fir and pine. Myers (1963) and Hann (1976) developed a linear model for Ponderosa pine and White fir with correlation of determination values of 0.99 and 0.98 , respectively. We have recorded higher values of beech $d b h$ estimates than those reported by Bylin (1982) whose model explained only $71 \%$ of the total $d b h$ variance due to a small sample size $(\mathrm{n}=15)$. Wharton's (1984) model explained slightly lower percentage (93\%) of the total $d b h$ variance for beech. Conversely, Ercanli et al. (2015) used mixed effect models for predicting $d b h$ from the stump diameter of Oriental beech with a coefficient of determination of 0.99. Thorpe et al. (2010) developed a linear model for black spruce explaining $97 \%$ of the total $d b h$ variance.

\subsection{Diameter-increment models}

Our models have shown that except for $d b h$, crown proportion ( $c p)$ and crown quality ( $c q$ ) variables are of higher importance than the other tree and stand variables. Furthermore, our study has confirmed that crown parameters might outweigh the influence of basal area proportion index CIg which was selected for this study as the best of five tested competition indices based on the study from similar mixed mature forests (Bošela et al. 2015). Thus they can be referred to as competition indices related to the radial growth. Crown parameters are more stable over time, thus providing information on past competition of trees in forest stands. As reported by Biging \& Dobbertin (1992), trees with large crowns are stronger competitors compared to trees with small crowns.

The best results of model fitting were obtained for spruce where the model incorporating only $d b h$, crown ratio and total growing stock per hectare explained $74 \%$ of variance in radial growth. Crown quality variable for spruce fell outside the set of predictors due to short term changes of foliage density caused by a sudden bark beetle attack. For fir, $d b h$, crown proportion, crown quality and stand mean diameter explained $69 \%$ of the radial increment variation. For beech, mean diameter was replaced by total growing stock per hectare and the model accounted for $57 \%$ of the total variation in radial growth. Only $34 \%$ of the total variance in radial increment was explained by quadratic mean diameter and site index for pine. This apparent lack of correlation can be partly attributed to shade intolerance of the species and a small sample size $(n=64)$. It may be assumed that emergent pines occupying dominant positions in the canopy have never been exposed to intense competition. This fact confirms previous findings in the literature (e.g. Stadt et al. 2007). Similarly to our results, Monserud and Sterba (1996) demonstrated that most of the variance in basal area increment was attributed to $d b h$ and crown ratio.

\subsection{Height-diameter models}

Weapplied the modified Michailoff's function(Michailoff 1943) to describe the tree height-diameter relationship for four targeted tree species. In addition, both $d b h$ and mean diameter of the stand $(d g)$ were considered 
as predictor variables. The inclusion of mean diameter into Michailoff's function has proved to be valid and has increased the accuracy of the tree height-diameter model. Temesgen and Gadow (2004) found that including BAL (basal area of large trees) as a predictor variable besides $d b h$ increases the accuracy of the height-diameter model for complex forest stands. Alternatively, Sharma \& Zhang (2004) included the basal area, number of trees per hectare and $d b h$ to improve their model's accuracy. Based on our evaluation statistics, we can conclude that our models performed satisfactorily. When comparing the model root mean squared errors (RMSE), we have found relatively small RMSEs for pine and spruce compared to two other tree species. Although the highest coefficient of determination was obtained for fir (0.87), the RMSE was the second highest $(3.64 \mathrm{~m})$. The model for beech had the lowest prediction accuracy with RMSE of $3.94 \mathrm{~m}$. This poor performance was not surprising. In fact, to accurately measure tree height is much more challenging for broadleaved trees than for conifers due to their differences in apical dominance and greater variability in the estimation of broadleaved tree heights (Garman et al.1995). Using long-term experimental plot data from mixed forest stands of spruce, fir and beech in the Western Carpathians, Petráš et al. (2014) created height-diameter models employing Michailoff's and Korf's function. Their data showed that the best model performance was obtained for fir with the coefficient of determination 0.94-0.95 and RMSE 1.94-1.97 m. Better results than those our are conditioned by long term data series and more or less even-aged stand structure. Recent studies suggest using general mixed effect height-diameter models rather than general ordinary least square models because of their higher prediction accuracy (Adamec 2015; Mehtätalo et al. 2015; Sharma et al. 2016). This could also improve modelling of heightdiameter relation in markedly uneven-aged forests. As noted by Crecente-Campo et al. (2014), species-specific models should be used for capturing at least the variation between tree species.

\subsection{Forest dynamics derived from real and reconstructed inventory}

Using real and statistically reconstructed previous inventory we recorded annual increment of 10 cubic meters per hectare, realistic in favourable growth conditions and stand structures in the study area. Our results are consistent with Saniga \& Szanyi (1998), who estimated a potential increment of $9-12$ and $8-10$ cubic meters per hectare, respectively, based on the results from two longterm research plots established within the study area. Slovak mean increment derived from mensuration data is 6.3 cubic meters per hectare (Moravčík et al. 2016) which also includes low production forests.

Suggested procedure based on a real and a statistically reconstructed past inventory seems to be more accu- rate and correct than simplified methods recommended by some authors for rough estimates of increment using yield tables and/or management records for the transition period when first inventory is missing (e.g. Záhradníček 2010). Furthermore, it provides a complete data set for calibration of relevant models for the appropriate management of uneven-aged forests, such as, matrix models, or traditional control methods.

\section{Conclusions}

In our study, we have proposed and verified an approach of using a set of three species specific models to reconstruct past forest status. Developed diameter-stump model, diameter increment model, and height-diameter model are simple and can easily be locally calibrated using standard inventory data combined with tree ring data.

Our results have shown that biometric relations and growth dynamics in mixed uneven-aged forests are strictly species specific. A high radial increment was related to trees with higher crown length and better crown quality, growing on fertile sites in younger growth stages. We are aware that results of our study are of only local validity, and models can be used for prediction only at a regional level and in specific uneven-aged mixed forest stands. Conversely, suggested procedure can be considered universal and applicable for any forest at the time of change from stand-based to plot-based inventories, related to a change from traditional even-aged to unevenaged forest management based on control methods and/ or population models.

\section{Acknowledgement}

The research was supported by the Slovak Research and Development Agency (Project APVV-0439-12: 60\%; Project APVV15-0265: 20\%), and by the Ministry of Agriculture and Rural Development of the Slovak Republic (Item No.08V0301-Project VIPLES: 20\%).

\section{References}

Adamec, Z., 2015: Comparison of linear mixed effects model and generalized model of the tree heightdiameter relationship. Journal of Forest Science, 61:439-447.

Bauhus, J., Puettmann, K. J., Kühne, Ch., 2014: Close-tonature forest management in Europe: does it support complexity and adaptability of forest ecosystems? In: Messier, Ch., Puettmann, K. J, Coates, K. D. (eds.): Managing Forests as Complex Adaptive Systems. Routledge London and New York, p. 187-213.

Biging, G. S., Dobbertin, M., 1992: A comparison of distance-dependent competition measures for height and basal area growth of individual conifer trees. Forest Science, 38:695-720. 
Biolley, H., 1887: Quelques réflexions sur le jardinage à propos des publications de M. Gurnaud. SchweizerischeZeitschrift für Forstwesen, 38:189-192.

Bošel'a, M., Tobin, B., Šebeň, V., Petráš, R., Larocque, G. R., 2015: Different mixtures of Norway spruce, silver fir, and European beech modify competitive interactions in central European mature mixed forests. Canadian Journal of Forest Research, 45:1577-1586.

Buongiorno, J., Michie, B. R., 1980: A matrix model of uneven-aged forest management. Forest Science, 26: 609-625.

Bylin, C. V., 1982: Estimating dbh from stump diameter for 15 southern species. Res. Note SO-286. New Orleans, LA: US Department of Agriculture, Forest Service, Southern Forest Experiment Station 3, 286 p.

Chhetri, D. B. K., Fowler, G. W., 1996: Estimating diameter at breast height and basal diameter of trees from stump measurements in Nepal's lower temperate broad-leaved forests. Forest Ecology and Management, 81:75-84.

Corral-Rivas, J. J., Barrio-Anta, M., Aguirre-Calderón, O. A., Diéguez-Aranda, U., 2007: Use of stump diameter to estimate diameter at breast height and tree volume for major pine species in El Salto, Durango (Mexico). Forestry, 80:29-40.

Crecente-Campo, F., Corral-Rivas, J. J., Vargas-Larreta, B., Wehenkel, C., 2014: Can random components explain differences in the height-diameter relationship in mixed uneven-aged stands? Annals of forest science, 71:51-70.

Dvorak, L., 2000: Kontrollstichproben im Plenterwald. Dissertation ETH Nr. 13 799. Eidgenössische Technische Hochschule Zürich.

Ercanli, I., Gunlu, A., Başkent, E. Z., 2015: Mixed effect models for predicting breast height diameter from stump diameter of Oriental beech in Göldağ. Scientia Agricola, 72:245-251.

Garman, S. L., Acker, S. A., Ohmann, J. L., Spies, T. A., 1995: Asymptotic height-diameter equations for twenty-four tree species in Western Oregon, Research Contribution 10, Forest Research Laboratory, Oregon State University, Corvallis, 22 p.

Hann, D. W., 1976: Relationship of stump diameter to diameter at breast height for seven tree species in Arizona and New Mexico. Dept. of Agriculture, Forest Service, Intermountain Forest and Range Experiment Station.

Hasenauer, H. (ed.), 2006: Sustainable Forest Management - Growth models for Europe. Springer, 398 p.

Leslie, P. H., 1945: The use of matrices in certain population mathematics. Biometrika, 33:183-212.

Mehtätalo, L., de-Miguel, S., Gregoire, T. G., 2015: Modeling height-diameter curves for prediction. Canadian Journal of Forest Research, 45:826-837.

Michailoff I., 1943:ZahlenmässigesVerfahrenfürdieAusführung der Bestandeshöhenkurven. ForstwissenschaftlichesCentralbatt - TharandterForstlichesJahrbuch, 6:273-279.
Möller, A., 1922: Der Dauerwaldgedanke - Sein Sinn und Seine Bedeutung. Springer-Verlag Berlin, $136 \mathrm{p}$.

Monserud, R. A., Sterba, H., 1996: A basal area increment model for individual trees growing in even and uneven-aged forest stands in Austria. Forest ecology and management, 80:57-80.

Moravčík, M. et al., 2016: Green report on the Slovak forestry 2015. Ministry of Agriculture of the Slovak Republic and National Forest Centre, $76 \mathrm{p}$.

Myers, C. A., 1963: Estimating volumes and diameters at breast height from stump diameters, southwestern ponderosa pine (Vol. 9). Rocky Mountain Forest and Range Experiment Station, Forest Service, US Department of Agriculture.

Olivier, C. D., Larson, B. C., 1996: Forest stands dynamics. John Wiley, New York, 520 p.

Özçelík, R., Brooks, J. R., Diamantopoulou, M. J., Wiant Jr, H.V., 2010: Estimating breast height diameter and volume from stump diameter for three economically important species in Turkey. Scandinavian Journal of Forest Research, 25:32-45.

Petráš, R., Bošela, M., Mecko, J., Oszlányi, J., Popa, I., 2014: Height-diameter models for mixed-species forests consisting of spruce, fir, and beech. Folia Forestalia Polonica, 56:93-104.

Pond, N. C., Froese, R. E., 2014: Evaluating published approaches for modelling diameter at breast height from stump dimensions. Forestry, 87:683-696.

Pukkala, T., 2016: Which type of forest management provides most ecosystem services? Forest Ecosystems, p. $2-16$.

Pukkala, T., Lähde, E., Laiho, O., 2009: Growth and yield models for uneven-sized stands in Finland. Forest Ecology and Management, 258:207-216.

Roessiger, J., Ficko, A., Clasen, C., Griess, V. C., Knoke, T., 2016: Variability in growth of trees in unevenaged stands displays the need for optimizing diversified harvest diameters. European Journal Forest Research, 135:283-295.

Saniga, M., Szanyi, O., 1998: Modely výberkových porastov vo vybraných lesných typoch a geografických celkoch Slovenska. Vedecké štúdie 4/1998/A. TU Zvolen, $50 \mathrm{p}$.

Sharma, M., Zhang, S. Y., 2004: Height-diameter models using stand characteristics for Pinus banksiana and Picea mariana. Scandinavian Journal of Forest Research, 19:442-451.

Stadt, K. J., Huston, C., Coates, K. D., Feng, Z., Dale, M. R., Lieffers, V. J., 2007: Evaluation of competition and light estimation indices for predicting diameter growth in mature boreal mixed forests. Annals of Forest Science, 64:477-490.

Temesgen, H., Gadow, K. V., 2004: Generalized heightdiameter models - an application for major tree species in complex stands of interior British Columbia. European Journal of Forest Research, 123:45-51. 
Thorpe, H. C., Vanderwel, M. C., Fuller, M. M., Thomas, S. C., Caspersen, J. P., 2010: Modelling stand development after partial harvests: an empirically based, spatially explicit analysis for lowland black spruce. Ecological Modelling, 221:256-267.

Wharton, E. H., 1984: Predicting diameter at breast height from stump diameters for northeastern tree species (Vol. 322). US Department of Agriculture, Forest Service, Northeastern Forest Experiment Station.
Záhradníček, J., 2010: Metodika hospodářské úpravy nepasečných hospodářských lesů. Ministerstvo životního prostředí České republiky, 59 p. 